\title{
Horizons/Théâtre
}

Revue d'études théâtrales

$14 \mid 2019$

Les arts du spectacle dans l'Afrique subsaharienne - 2

\section{Playing with Arts and Identity in Koffi Kwahulés Recent Theatre: Basquiat and Fela Kuti}

Judith G. Miller and Rachel M. Watson

\section{(2) OpenEdition}

1 Journals

Electronic version

URL: https://journals.openedition.org/ht/1638

DOI: $10.4000 /$ ht. 1638

ISSN: 2678-5420

Publisher

Presses universitaires de Bordeaux

Printed version

Date of publication: 1 January 2019

Number of pages: 108-124

ISBN: 979-10-300-0718-3

ISSN: 2261-4591

Electronic reference

Judith G. Miller and Rachel M. Watson, "Playing with Arts and Identity in Koffı Kwahulé's Recent Theatre: Basquiat and Fela Kuti", Horizons/Théâtre [Online], 14 | 2019, Online since 01 June 2022 connection on 30 June 2022. URL: http://journals.openedition.org/ht/1638 ; DOI: https://doi.org/ 10.4000/ht. 1638

\section{(2) $(\mathcal{Q} \Theta \Theta$}

La revue Horizons/Théâtre est mise à disposition selon les termes de la Licence Creative Commons Attribution - Pas d'Utilisation Commerciale - Pas de Modification 4.0 International. 


\section{JUdith G. MilleR, RACHEL M. WATSON}

Judith G. Miller is Professor of French and Francophone Theatre at New York University. Her most recent publication is a translation of Béatrice Picon-Vallin's history of the Théâtre du Soleil - The Théâtre du Soleil: The First Fifty-Five Years (Routledge, 2020). She is currently translating works for an anthology of African Francophone plays and finishing a chapter on "Francophone African Theatre in France" for a new history of French theatre (Ed. Clare Finburgh, Cambridge, projected 2022). Rachel M. Watson is a Ph.D. candidate in the Department of French Literature, Thought, and Culture of New York University, where she studies 20th and 21 st century French and Francophone theatre and performance. Her most recent publication, an article on the Soleil company playwright, Hélène Cixous, is forthcoming in the Routledge Anthology of Women's Theatre Theory \& Dramatic Criticism. Her Ph.D. thesis examines embodied memory and intermediality in the Théâtre du Soleil, Wajdi Mouawad, and Koffi Kwahulé.

Mail : judith.miller@nyu.edu

Abstract: "Playing With Arts and Identity in Koffi Kwahulés Recent Theatre: Basquiat and Fela Kuti" situates Kwahulé's theatre within the trajectory of Francophone African theatre that queries notions of identity and politics. It sees Kwahulés work as part of a movement that turns away from questions of colonization and decolonization to trouble the center and periphery paradigm of postcoloniality. Kwahulé adds a transnational dimension, especially through the use of jazz motifs. He constructs in his plays an identity in constant motion, an identity that refuses borders and transforms through contact and improvisation. In recent works, notably the focus of this essay, SAMO: $A$ Tribute to Basquiatand Kalakuta Dream: A Tribute to Fela Kuti (both written in 2015), Kwahulé incorporates jazz and rap strategies of scrambling lines, repeating phrasing, riffing while rhyming, and syncopation to capture textually the particular aesthetics

Résumé : Dans ses récentes pièces, le dramaturge ivoirien Koffi Kwahulé essaie de capter à travers une écriture et une structure dramatique expérimentales les gestes et le feeling des artistes, et surtout des musiciens qu'il admire. Entre 2015 et 2016 il a écrit un texte en hommage au peintre américain Jean-Michel Basquiat (SAMO: Tribute to Basquiat) et un autre inédit au musicien nigérian Fela Kuti (Kalakuta Dream: Tribute to Fela). La distribution des rôles, la musicalité de la prose, les répétitions et les refrains, et la juxtaposition des styles communiquent à la fois l'énergie, la charge politique de of both artists. Through musicality, Kwahulé grasps the vibrancy and collage techniques in Jean-Michel Basquiat's canvases. SAMO thus becomes not only an exploration of Basquiat's hybrid identity but also a theatrical transposition of how Basquiat's paintings "speak." Kalakuta Dream, more a surreal sketch than aplay, invites actors, dancers, and musicians to realize a political commentary through instrumentation. Kwahulés Fela Kuti, iconoclastic and gutsy, dreaming of another, and freer, universe in his Kalakuta "Republic," skewers dictatorial power through irreverent behavior,including trenchant music. Innovative and challenging, both plays foreground the feints and dodges necessary to survive an increasingly materialistic world.

KeYwords: intermediality, rap, graffiti, artist, jazz, African theatre.

l'œuvre explosive de Basquiat de même que la musique révolutionnaire et corrosive de Fela. Nous analysons ces innovations intermédiales, tout en inscrivant Kwahulé dans une nouvelle génération d'auteurs africains pour qui une certaine hybridité technique, un déplacement de la centralité du conflit colonisateur/colonisé, une considération des relations entre l'Afrique et ses diasporas prennent le devant sur une scène théâtrale de plus en plus transnationale.

Mots-cLés: intermédialité, rap, graffeur, jazz, théâtre africain. 


\section{Playing with Arts and Identity in Koffi Kwahulé's Recent Theatre: Basquiat and Fela Kuti}

WE Might CONSIDER Aimé CÉSAIRE'S SEARING INDICTMENT OF EUROPE, "L'Europe est indéfendable !," in his Discours sur le Colonialisme (1950), as the philosophical underpinning of much of African francophone theatre of the 1960s and 1970s ${ }^{1}$. Whether by Bernard Dadié (Béatrice du Congo, 1970), Senouvo Agbota Zinsou (On joue la comédie, 1975), or by Césaire himself (Une Saison au Congo, 1967), plays from or about the continent take to task, often ironically and sometimes hilariously, Europe's civilizing mission, its imposition of hierarchies and customs, its exploitation of resources, including human beings, and its complicit hook ups with American neo-colonialists and African strongmen who transitioned the continent from colonies to capitalist fiefdoms. As Césaire himself admonishes: “C'est une société nouvelle qu'il nous faut, avec l'aide de tous nos frères esclaves, créer, riche de toute la puissance productive moderne, chaude de toute la fraternité antique ${ }^{2}$."

By the dawning of the 1990s, the theatrical rage and furious denunciation found in the earlier African pieces had been redirected to the strongmen themselves, those ruling individual countries - like the absurdist dictators that haunt the plays of Sony Labou Tansi, plays such as La Parenthèse $d u$ sang (1981), where military henchmen are charged with looking for but never finding the origins of liberty. This self-flagellating and often self-satirizing strand of African theatre continues to this day, as seen in the plays of the newest generation of writers, playwrights such as the Burkinabé Aristide Tarnagda or the Togolese Gustave Akakpo who worry about Africans'ability to heal African wounds, thereby giving credence to afro-pessimism ${ }^{3}$.

Nevertheless, during the decade of the 1990s and right up to the present, a sea change in African francophone theatre has begun to make itself known, a change that critic Sylvie Chalaye has dubbed "Frankensteinian". The central conflicts of African v. European or colonized v. colonizer have morphed into a battle between values and mentalities, mentalities that show the strains and tensions of an ever-globalizing world. Is female empowerment, for example, compatible with a healthy village ecology (as in Werewere Liking's Singué Mura, 1990)? Can an African teenager, immigrated to France, escape from 
patriarchal authority to build an alternative family (as in Koffi Kwahulé's Bintou, 1997)?

Kwahulé's play Bintou also announces the beginning of what we might think of as engagement with a different kind of theorizing of African and diasporic identity. His work resonates particularly with Edouard Glissant's notions in Poétique de la relation, 1990. Glissant theorizes the non-fixity of borders; subjectivity being a dance of relations ; and slavery, or the commerce in humans, as central to crafting the story of the world's modernity. This refusal of stasis has brought an entire other continent and the Atlantic Ocean into the francophone African dramatic realm, the most recent and extravagant example of this tendency being Léonora Miano's three-part play, Red in blue trilogie $(2015)^{5}$.

In line with Glissant's thinking, Kwahulé begins to unsettle the privileged places of Africa and Europe in theatrical considerations of identity, and, especially, to find in references to American jazz a way of bringing to the fore theatrically one of the great contributions of Africans and African-descended peoples ${ }^{6}$. We see Kwahulé's strategy of decentering Europe in operation, for example, in his Cette vieille magie noire, 1993; Jaz, 1998; and Misterioso 119, 2005. Through riffs and refrains, through embodying jazz as a character or as a major component of the narrative, Kwahule gives shape and depth to his sense of connectivity beyond national borders. In this geographical move, he finds energy in pondering the potential of the future, rather than lamenting a lost past.

Kwahulé's plays project a universe in motion, a coming into being, a building of identity through improvisation and hybrid aesthetic forms - what he has called in his essays in Frères de Son, 2007, the art of constructing a paradoxical, because ephemeral, "monument" in order to capture the current human condition, one vibrating with the experience of slaves in the New World - a situation of dispersal, exile, and longing. In two of his more recent works, SAMO: a tribute to Basquiat and Kalakuta Dream: a tribute to Fela, both written in 2015, he grapples with the lives of artists, one African-American, one African ${ }^{7}$, to place on stage a liberating theatrical aesthetic that includes a refusal to be boxed in personally as well as politically and a demand to be seen as part of a continuum of world artists ${ }^{8}$.

Kwahulé focuses on a particularly fraught moment of each artist's life as a way of making meaning with a story that in production becomes part of a vast intermedial score, one that speaks through colors, movement, rhythm, and sonority, as much as through semantic fields. Borrowing Basquiat's and 
Fela's own strategy of quoting other artists or arts movements in fractured or hybrid form, Kwahulé creates in each case an assemblage that plays with notions of identity, while celebrating the freedom to create and recreate a new self. Kwahulé finds kinship and subject matter in these two multi-faceted artists - who, themselves, whether in painting or composing, engage with the ebullience of subversive musical forms to challenge conventions and find their places across worlds ${ }^{9}$. In what follows, we will delve into how Kwahulé connects his texts with the aesthetics of Basquiat and Fela, and how, in doing so, he begins to communicate the liberating, transnational identity that both artists forge in their work ${ }^{10}$.

$S A M O$, the more resonant and developed of the two plays under discussion, realizes a theatrical voyage in seventeen segments that captures through juxtapositions and ruptures Basquiat's move from childhood to his activities as the graffiti artist SAMO, on the cusp of becoming "Jean-Michel Basquiat, the celebrated painter." Kwahulé opens in hopped-up and associative thought patterns the "chrysalide" who will explode on the New York art scene. A spoken word piece more than a dramatic text, most segments in rap format, SAMO communicates through rhythm, rhyme, refrains, and riffs the chaos, the color, the hectic ambition, the anger, and the charm of this exceptional artist - a trickster if there ever was one - and his rapport with his father and mother, with white America, with the racial context of his times, with his arts family, and with the arts establishment. Created, as Kwahule tells us on the front page of the script, for musicians, dancers, and actors, this "play" leaves directors free to distribute the lines as they wish ${ }^{11}$.

In SAMO, Kwahulé expertly grasps the interplay of the different art forms, namely musical and visual, in Basquiat's work. The playwright is adept at depicting jazz's influence, both thematic and stylistic, on the painter. Much has been made by art historians, critics, and curators about the role music - rap, hip-hop, and funk, but above all, jazz - played in shaping Basquiat's work. The 2017 retrospective at the Barbican Center, "Basquiat: Boom for Real," focused on the artist's interest in intermediality. Text, film, and television were represented but, as critic Ekow Eshun recounts: "Jazz - the musical style that made up the bulk of Basquiat's huge record collection - [...] looms largest as a source of personal inspiration to him and as subject matter ${ }^{12}$ ". Robert Farris Thompson, art historian and personal friend of Basquiat, claims the same emphasis, maintaining that: "[ $]$ ]azz and blues are prominent, consciously chosen Afro-Atlantic roots. They appear as content, they appear as names, they appear as style ${ }^{13}$." Thompson's description of watching Basquiat paint 
at home in his apartment lends insight into why and how his canvases are "musically parlous":

Basquiat activated an LP of free, Afro-Cuban, and other kinds of jazz. Then he resumed work on an unfinished collage. Hard bop sounded. Jean-Michel pasted on letters and crocodiles. He did this with a riffing insistence, matching the music. Digits in shifting sequences, 222 2, 44 4, 555 5, further musicalized the canvas [...]. He continued to work. Four styles of jazz - free, mambo-inflected, hard bop, and, at the end, fabulous early bop with sudden stops - accompanied the making of the collage ${ }^{14}$.

Because Basquiat was steeped in music while he worked, it is no surprise that his canvases display a transfer of jazz and rap: visual rhythm, harmony and dissonance, riff, improvisation, "syncopated words, with passages of color" and "texts [falling] into rhyming discordancies, not unlike the rise of rap $^{15 "}$. In order to fully capture for the stage the musicality of Basquiat's work, its auditory and kinetic energy, Kwahulé, who not unlike Basquiat frequently works while listening to jazz, has produced a text equally influenced by jazz techniques, equally "musically parlous."

The musicality of Kwahulé's text is established almost immediately in the second segment of the work, the first of three florid reviews of art pieces (2, 8,13 ) scattered throughout the play, in which a voice (Basquiat's, although the character is never named), attacks in hammered prose the superficiality, even the deadliness, of what is supposed to be good art: "Une simulation de la beauté de l'été ${ }^{16}$." This kind of simulation, the pretense of seeing too much when there is nothing to be seen, is what Basquiat calls: "toujours la même vieille merde," that is, "the same old shit" - or SAMO. This is the moniker that will launch him on his career as adored delinquent, street poet of the marginalized. This is also the tough-sounding and emphatic syllabification - same old shit - that undergirds the free-verse rap throughout Kwahulé's play.

An ever-greater pulsing of musical emotion makes itself felt in the segments of $S A M O$ in which Basquiat raps specifically about his national and supposed psychological identity. Not only is he "American," he insists, contrary to the "primitive Haitian other" the interviewers he encounters would like him to be (Segments 3, 9, 11), but he is also a kind of wordsmith who plays with order and hierarchy, creating a personal mantra that extends before and beyond "SAMO:" "Suis né à l'heure exacte où la vie ceint sa couronne de soleil. / Suis né où la vie ceint à l'heure exacte sa couronne de soleil. / Suis à l'heure exacte né la où soleil ceint sa couronne de vie" and so on for another four $\operatorname{lines}^{17}$. Thus Kwahulé, in creating the Basquiat voice, scrambles syntax, re- 
plays sonorities in slightly different order, and encapsulates the boy-man in a kind of brightness that is both aura (corona) and crown - the latter a figure repeated again and again in Basquiat's paintings.

In this third sequence, Kwahulé takes up an almost fugal form, staging a kind of 1940s jazz fugue - a musicality that captures Basquiat's favorite form of jazz. Although the text is limited to a single voice, whereas true fugues are accomplished by multiple instruments or voices, the syntactic rearrangement results in fugue-like repetition: the "melody," stated in the first line, is taken up by each subsequent line. The feeling is one of repetitive shuffle, the variations in the text creating the effect of multiple lines played on top of each other. Kwahulé's poetry approximates with brio this contrapuntal technique. What we have called the "melody" of the fugue: "Suis né à l'heure exacte où la vie ceint sa couronne de soleil. / I was born exactly when life embraces the crown of the sun," is again rapped by Basquiat in the final segment of the play $^{18}$. Like Basquiat, Kwahulé performs autocollage, in the playwright's case collaging his own text in order to use it like a musical refrain. Kwahulé thus places his work, and his depiction of Basquiat, in kinship with the AfricanAmerican art tradition, through which, as art historian Richard Powell tells us, runs a blues aesthetic that features a "collage sensibility ${ }^{19}$."

In Segment 4, Kwahulé concentrates on one image, la rate (the spleen) that will accrue meaning as it spirals through the passage. The Basquiat voice tangles with the multiple meanings of this term, all in recounting a central moment in his childhood when he was hit by a car and lost his spleen. No spleen means no purifying resource for what assaults the body. No spleen means no way to protect oneself from the emotional impact of the world. But no spleen also means running without barriers - thereby skirting the melancholy that overwhelmed that other vagabond poet obsessed with spleen, Baudelaire.

In this passage, Kwahulé, as usual, rearranges and reorders the phrasing of Basquiat's story: "Je l'enfant ne voit pas la voiture arriver. / [...] La voiture ne voit pas l'enfant je." He thus creates a narrative that circles backwards and forwards, holding together hauntingly the child that Basquiat was and the voice that recounts the child. This concurrent double narration lends to the segment not only a Cubist aesthetic - one in which the figure is depicted from various points of view simultaneously - but also mirrors a musical scale played in contrary motion by two instruments or two hands. "Les automobiles sont immobiles," Basquiat chants, the assonance of the line echoing in much of the phrasing throughout the rest of the play, phrasing that will fore- 
ground other plosive and sibilant sounds like so many beats on a snare drum ${ }^{20}$. This "splenetic" passage exhibits the acuity with which Kwahulé transfers into theatrical poetry the Cubist and jazz influences evident in Basquiat's own compositions.

Furthermore, by referencing "spleen," especially in the context of a play about an outsized street artist - a kind of decadent artiste maudit in whose apartment drugs, expensive bottles of wine, wadded-up hundred dollar bills, and women clad in bed sheets littered the floor - Kwahulé summons into the dramatic space the specter of those well-known poètes maudits of the French tradition, who too found inspiration and material in intoxication and the streets. The reference specifically to Baudelaire appears again, in both SAMO and Kalakuta Dream, when Kwahulé uses a combination of adjectives reminiscent of the "luxe, calme et volupté" in Baudelaire's Invitation au voyage. $S A M O$ 's hope for a rapturous "douceur et volupté" and Fela's dream of a city that "n'est que calme, volupté, et bonheur" place Basquiat and Fela in Baudelaire's orbit of sensuous reverie, all three residing outside the norms of the dominant culture and creating art in search of a "pays qui [leur] ressemble ${ }^{21}$."

The longest segments in SAMO, and in some ways the most heartfelt (5, $10,15)$, set up dueling raps between Basquiat and his father. These passages again follow rap's rules of repetition, refrain, and rhyming, while jumbling up syntax and syncopating rhythms by putting stress on specific words. Just as, according to Thompson, Basquiat "staggers the phrasings" of color grounds and text in his paintings to reflect "the Africanizing trait of suspended accentuation," Kwahulé molds and shapes the phrasing of the father's and son's rap lines - sometimes using line breaks, other times dashes - to syncopate a rhythm or to highlight a beat by allowing a several beats rest ${ }^{22}$. This rhythmic accentuation - achieved with more difficulty in French than in English, due to the former's lack of tonic stresses - was also used famously by Charlie Parker, a jazz hero to both Basquiat and Kwahulé.

Basquiat's father makes us hear through repetition how the music JeanMichel plays starts the eardrums crying: "Pleurer les tympans / Les tympans pleurer / Pleurer les tympans," positioning the boy in his own universe of synesthesia, rather than in the confines of a form of violent discipline the patriarch himself champions ${ }^{23}$. Basquiat escapes this kind of "discipline" - a word, nevertheless, the father bellows out five times as the final term of his endless scolding (Segment 5). In the rap duel in Segment 10, Kwahule orchestrates Basquiat's response to such enraged disappointment by quoting a 
series of SAMO's graffiti taunts, aimed at the world his father would have him venerate.

These contrastive raps between generations are punctuated by specific jazz tunes to help set the mood or to make a statement, a technique Kwahulé uses in earlier plays as well ${ }^{24}$. In Segment 7, for example, Basquiat mentions listening to a Julie Andrew's rendition of Richard Rodgers's My Favorite Things (in Andrews'phrasing, this becomes a song meant for children that evacuates the pain of living.) In Segment 15, his father hears the song in several moments, through solos by Steve Davis, McCoy Tyner, Elvin Jones, and finally and most consequentially, John Coltrane. Coltrane's reworking makes his own pain palpable, seared into musical memory. In all cases, the musical register is supremely ironic, as My Favorite Things reminds Basquiat of driving with his mother as she seemed about to run her car, with her children in it, off a cliff. When the father hears Coltrane's lament, he is, on the contrary, slowly coming around to accepting his son's new spiritual father, the albino-haired Andy Warhol.

Charlie Parker's figure looms large here too. Kwahulé tells us in Segment 5 that one of the reasons Basquiat loved his father, despite his violence, was because of his resemblance to Charlie Parker. And Charlie Parker, that other spiritual father to Basquiat, often proclaimed loudly that the only discipline necessary to art - in his case, music - was the discipline necessary to break boundaries, in full consciousness of the breakage. Kwahulé seems to be following Parker's iconoclastic directive by transferring musical strategies into his dramatic poetry. Not only does he sample famous songs to texture his scenes, but he also breaks disciplinary boundaries by borrowing consciously from musical paradigms. Indeed, Charlie Parker's musical style - one described by Marshall W. Stearns as alternately "hot": "tortured, searing, blasting [and] reminiscent of the shouting congregations in the South" and "cool": with "oblique lyricism, gentle indirection, and almost apologetic nuances," is mirrored in Kwahulé's rap duel-just as it is in Basquiat's paintings ${ }^{25}$.

Blowing hot in Segment 10 to counter his father's suggestion that tagging is not art, Kwahulé's Basquiat screams: "Je n'ai jamais fait de tag / [...] / Je fais de la peinture depuis mes débuts ${ }^{26}$." And in Section 5, cooler-toned, Basquiat gently and almost sweetly exclaims: "De lui [son père] ce que / J'aime le plus / Que / Il m'appelle Jean. / Pas Jean-Michel comme tout le monde / Jean. / Et aussi pour sa resemblance avec Bird ${ }^{27}$." Basquiat's hot yellows and cool blues, which, as Thompson points out, give material shape to Parker's playing (as in Basquiat's canvases Jazz and Zydeco, Horn Players, and Charles the First) 
are here translated to the stage through Kwahulés rap-like poetry ${ }^{28}$. Through a rich layering of jazz aesthetics - moving first from the horn to the canvas and then from the canvas to the stage - Kwahulé adds contrasting tones to his excavation of Basquiat's identity, appropriating the streak of independence and the feeling of longing that colors it.

Kwahulé further explores Basquiat's identity, marking him as a tagger, by foregrounding both textually and physically the snappiness and irreverence of his work. In Segment 12, Basquiat tells us he likes giving the white establishment what they want: that is, the portrait of a petty criminal, a homeless devil, a disrespectful genius. If it serves his purpose, he willingly impersonates what others want to see. And this impersonation, in Kwahulé's version, takes the form of doubling the excessive physicalization of tagging by dancing. For example, in Segment 10, while Basquiat dances, his father castigates rhythmically his unruliness and vandalism. Yet he admires how everyone sees his son as a god when he dances. And he repeats: "Que tout en toi est grâce. Que tu es grâce. $[. .$.$] La grâce. [...] La grâce. [... La grace { }^{29}$." The father thus acknowledges how his own son, dancing across the stage, has become both untouchable and aspirational to him and others. Drawn in by his son's charisma and incipient fame but also repelled by his scandalous behavior, the father's exclamatory "la grace » evolves through repetition to signify awe and, simultaneously, to implore God's mercy for his delinquent boy.

In the often ambiguous way in which rappers play with their identity, Basquiat, via Kwahulé, attempts to distance himself from the label of "tagger" or "graffiti artist." In Segment 7, which celebrates the centrality of the arts education Basquiat received when accompanying his anguished and talented mother to museums and galleries in New York, Basquiat comes to identify strongly, according to Kwahulé's emphasis on lists of artists, with Picasso and especially with Picasso's Guernica. As Kwahulé gives us to understand it, Basquiat's logic in comparing Guernica to his tags is the following: if Picasso is a great artist whose graphic sensibility, controlled chaos, and ethical commitment against fascist aggression are all present in a work like Guernica (1937), then I, too, Jean-Michel Basquiat, following in Picasso's aesthetic and political footsteps and similarly committed to protest, am a true artist - not just a mere tagger.

Basquiat, the trickster, the clever dissimulator, has, like rappers in general (and clearly in Kwahulé's portrait of him) a serious message to deliver. He does so in an easy switching of codes. Moving between high and popular forms and among languages (English, Spanish, and some Italian), passing 
from irony to gravitas, he punches the world with trenchant and socially abrasive tags, such as: "SAMOC as an alternative 2 'playing art'with the 'radical chic'sect on Daddy's $\$$ funds ${ }^{30}$." While he delights in taking advantage of the naivety of the rich and the so-called arts connoisseurs, Kwahulés Basquiat unquestionably has a project he intends to realize. We see this compellingly in Segment 12: "Faire entrer dans les plus grands musées du monde / La rue les têtes crépues trouées de rires joyeux et inquiétants ${ }^{31}$." In other words, Basquiat's bad boy persona and his trickster rabble-rousing are the basis of a collective portrait of African-Americans, those who, like him, have survived by detours and indirection and who deserve to have their story told and validated through art. This is, of course, the validation also provided by Kwahulé.

If Kwahulé elevates the artist from ordinary "tagger" by placing him in a line of succession of boundary-breaking painters like Picasso (whose portrait Basquiat realized in the style of Picasso's harlequins), then he also does so by repeatedly signaling through referencing them Basquiat's deep knowledge of African-American music and musicians, athletes, and global civil rights heroes. Highlighting these influences on Basquiat, Kwahulé underscores a work informed, inspired, and grounded in history and art history, as well as in the civil rights movement. As Basquiat himself revealed in a 1985 interview: "I have to have some source material around me to work off [of ] ... magazines [and] textbooks... ${ }^{32 "}$ Listening to jazz or funk records, reading about Jim Crow laws all find a way into his art.

Kwahulé brilliantly apprehends the influence of these sources in Basquiat's work in the short impactful Segment 6, which takes the form of a naming sequence. Here, Kwahulé first distills into a short rap the American civil rights battle threading through Basquiat's work. He creates two parallel musical lines, a rhythmic repetition of "Mississippi" punctuating the ironic question that undercuts it: "Est-il raisonnable de penser que les quatre millions d'esclaves qui viennent de passer de la servitude à la liberté possèdent les qualifications nécessaires leur donnant titre aux privilèges et aux immunités de citoyens ?" In this opening moment of the segment, Kwahulé renders verbally Basquiat's interrogations in his paintings: Jim Crow and Undiscovered Genius of the Mississippi Delta. These sprawling canvases, covered with repetitions of the word "Mississippi," acknowledge the institutionalized racism of America's Deep South, while also challenging racist mentalities by celebrating AfricanAmerican culture and resistance.

Next, Kwahulé has the character Basquiat rap a list of names of influential African-American musicians - particularly jazz musicians (Thelonius Monk, 
Billie Holiday, Charlie Parker, John Coltrane), civil rights heroes (Martin Luther King, Harriet Tubman, Malcolm X, Rosa Parks, Nelson Mandela, Angela Davis), and athletes and writers engaged in the rights struggle (Amiri Baraka, Muhammed Ali, Joe Louis, Jackie Robinson, [Hank] Aaron). This textual composition sounds out the names and figures that take shape on Basquiat's canvases, while reminding the audience of the oppressive forces (such as "Jim Crow" or "FBI") against which these figures, and Basquiat among them, have had to fight.

Kwahulés choice to list names as a poetic strategy is related to the syncopated rhythms of jazz and rap and illustrative of the texture and movement of Basquiat's paintings. Travis A. Jackson tells us that the African-American poet Amiri Baraka in his compositions with jazz musicians Steve McCall and David Murray also draws on the "tradition of naming, [which] [...] has its exemplars in edgy poets Walt Whitman and Allen Ginsberg ${ }^{33}$." The voicing of names in jazz, as in Kwahulé's naming riff, is a strategy of detour and deviation from the hegemonic historical narrative. It spotlights an alternative history and champions another, African-based, tradition. Moreover, Kwahule's architecture of the list - the spaces or rests between names dictating tempo and beat - poetically mirrors the slashing, dashing, almost jabbing movement of Basquiat's brushstrokes, lines, and text ${ }^{34}$. The playwright suspends accentuation in the speaking of names, just as the painter syncopates the beat of the viewer's eye as it moves over slashes on alternating color grounds.

Ultimately, this $6^{\text {th }}$ segment of the play condenses powerfully the aesthetic qualities and important themes of Basquiat's work. The kaleidoscopic constellation of names, strung out/sung out by Basquiat - the painter, tagger, dancer, rapper - situates him palpably within a genealogy of resistors, civil rights heroes, and martyrs of the twentieth century, from Emmet Till to Nelson Mandela to all those fighters for equality in that magically sibilant Southern state: Mississippi.

Finally, just as Kwahulé foregrounds African-American cultural and aesthetic references in Basquiat's work, he also shows how Africa simultaneously seeps in. (This is evident in Basquiat's paintings, in part, in his recurrent masklike portraits.) In Kwahulé's play, the emphasis on vibrant colors, on percussive movement, connects Basquiat back to the continent from which his father's people hailed. Like jazz, also the reflection of a voyage that transforms continuously and transcends boundaries, SAMO shows us that Basquiat's art never stands still. His bold strokes, patterns, and stunning color juxtapositions seize America, his America, especially New York City, as a melting pot, 
a space vital and alive even in the face of white supremacy - a space that holds the cultural memory of Africa within an ever-changing mixture of influences. And Basquiat, via Kwahulé's poetic shaping, claims a space outside of any box, mirthfully challenging established forms and conventions.

In Kwahulés Kalakuta Dream, this out-of-the-box space takes over the stage. At first glance more conventional than SAMO, because three characters (Felamojoh, Sandra, and Barry) are actually named and have lines attributed to them, under further inspection Kalakuta Dream is just as innovative, because these three characters evolve into others who cannot always be situated. Moreover, the play on the whole is less a story than a surreal fantasy, a prop again "for musicians, dancers, and actors" to jam and rap and thus create on stage the affective intensity that Fela radiated ${ }^{35}$. Kwahulé here has especially carved out the moment in Fela's turbulent life when he, becoming politicized, sets up in the 1970s his Kalakuta Republic, a nation inside the nation. This arts compound of total freedom permitted him to become the voice of the people oppressed by dictatorship. Again like a crafty trickster, Kwahulé's Fela speaks the truth to power. And in trickster style, the real Fela gave as name to his home base the same name (Kalakuta) as that of the jail in which he had been imprisoned.

In Kalakuta Dream, Kwahulé hints at the storied elements that made Fela himself a space on which to project others'fantasies: the powerful political mother, Funmilayo Kuti; the thirty wives living with him; the drugs; the fearlessness ; the American girlfriend. What Kwahulé insists on, however, are a few themes and an emotional palette in sketch form that makes Kalakuta Dream both an inversion of and a complement to what SAMO accomplishes on stage. In other terms, Kwahulé hands over to the musicians the task of making the music heard instead of incorporating musicality and jazz strategies into his text, while highlighting again, but in vignettes, the role of AfricanAmerican culture as catalyzer, as well as stressing the necessity for the African artist to feint and dodge in order to get at the truth ; the always present danger of betrayal, even by those who are closest; and the ultimate victory of art itself.

The strongest of these vignettes includes the opening scene, in which Kwahulé emphasizes the connection between African and African-American identity. Waiting for Fela to arrive, Sandra - the character based on the real life African-American Sandra Smith Iszadore, who did indeed introduce Fela to the political vision of the Black Panthers and to liberationist thinking - describes her childhood in Stockbridge, Massachusetts ${ }^{36}$. This perfect 
American childhood - perfectly mythically white that is - seems to mask an anger that Sandra has transferred onto Fela, expecting him to lead the charge against discrimination, intimidation, and oppression. His response will be found in the brilliantly brassy music played between and underneath scenes.

Fela's impishness and his irreverence are rendered grotesquely funny when he tricks the two cops who have come to arrest him. He invites them to smoke the joint they have recuperated from his excrement. (He had earlier swallowed it to avoid detection.) Their mutual enjoyment of "the weed" destroys the evidence of his drug habit, while at the same time filling them up literally and metaphorically with his "shit ${ }^{37}$." This is the kind of transgressive humor Kwahulé has used to lambast elsewhere the military, as in his anti-war play Brasserie, 2006, and it is also the kind of broad farce that characterizes concert-party performances throughout Africa. In Kalakuta Dream, Fela's upside-down clownishness will be carried forward in other musical numbers, the style and tenor of which being left to the on-stage musicians to work out.

If $S A M O$ shows Basquiat becoming Basquiat and repurposing his adolescence through raps and refrains, Kalakuta Dream shows a Fela who exists only in his music - the musical support for the performance thus becoming the core element of this show ${ }^{38}$. All we see of him on stage is a mythification, a kind of allegory in which he is primarily seen by others, as alternately the African politicized by an African-American, a scamp who escapes the clutches of the police by staging a farce, a Christ figure betrayed by his best friend, and an artist who will not stop producing art even after his home has been burned down and his mother thrown out the window to her death. Kwahule's Fela is called Felamojoh because he never loses his magic mojoh nor stops being a supernatural hero.

In this analysis, we have hoped to demonstrate how, especially in SAMO but also in Kalakuta Dream, Koffi Kwahulé makes present and felt the impact of other arts on writing for the stage. We have suggested that his recent plays physicalize on stage what other arts can do to create spaces outside of authority, to elevate the "people's" art, and to make connections and suggest resonances that bypass entrenched political and historical divisions. In paying homage, as he does, to Jean-Michel Basquiat and Fela Kuti, Kwahulé reconnects with the transgressive nature of African popular performance and positions America, especially African-American culture, as central to a vision of artistic resistance, while locating in both artists traces of the poètes maudits ever present in the history of French and world art. Might not these plays, then, be a good illustration of the Glissantian "universel", in which different 
cultures in contact with each other place themselves in a movement of perpetual reinvention, a "universel" in which cultures already fused with an African past find new energy in a transnational African future?

\section{Works Consulted}

Baudelaire, Charles, "Invitation au voyage", Les Fleurs du mal, Paris, Gallimard, 1996.

Bischofberger, Bruno and SLAE, Jean-Michel Basquiat, Milan, Charta, 1999.

Buchhart, Dieter and Sam, Keller (eds), Basquiat, Riehen/Basel, Beyeler Museum AG; Ostfildern, Hatje Cantz, 2010.

Césaire, Aimé, Discours sur le Colonialisme, Paris, Présence Africaine, 1989.

—, Une Saison au Congo, Paris, Seuil, 1974.

Chalaye, Sylvie, Le Syndrôme Frankenstein, Paris, Éditions Théâtrales, 2004.

Collins, John, Kalakuta Notes, Middletown, Wesleyan University Press, 2015.

Dadié, Bernard, Béatrice du Congo, Paris, Présence Africaine, 1970.

Eshun, Ekow, "Bowie, Bach, and Bebop : How Music Powered Basquiat", New York Times, 22 September 2017, online.

Glissant, Édouard, Poétique de la relation, Paris, Gallimard, 1990.

Higginson, Pim, Scoring Race, Jazz, Fiction, and Francophone Africa, London, James Currey, 2017.

Kwahulé, Koffi, Big Shoot/P'tite Souillure, Paris, Éditions Théâtrales, 2000.

—, Bintou, Brussels, Lansman, 1997.

— B Brasserie, Paris, Éditions Théâtrales, 2006.

— Cette vieille magie noire, Brussels, Lansman, 2006.

- Kalakuta Dream: a tribute to Fela,not published, paginated.

- Le Sas/Jaz/André : Monologues pour femmes, 1998, Paris, Éditions Théâtrales, 2007.

—, Misterioso-119/Blue-S-Cat. Paris : Éditions Théâtrales, 2005.

_- SAMO: a tribute to Basquiat. Not published, paginated.

Kwahulé, Koffi and Gilles, Mouëllic, Frères de son, Paris, Éditions Théâtrales, 2007.

Labou Tansi, Sony, La Parenthèse du sang, Paris, Hatier, 2002.

Liking, Werewere, Singué Mura ou considérant que la femme..., Abidjan, Eyo Ki-Yi Éditions, 1990.

Lock, Graham, and David Murray (eds), The Hearing Eye: Jazz E Blues Influences in African American Visual Art, New York, Oxford University Press, 2009.

Miano, Léonora, Red in blue trilogie, Paris, L'Arche, 2015.

Olaniyan, Tejumolo, Arrest the Music! Fela and His Real Art and Politics, Bloomington, Indiana University Press, 2004. 
O’Meally, Robert G., Brent Hayes Edwards and Farah Jasmine Griffin (eds), Uptown Conversation: the new jazz studies, New York: Columbia University Press, 2004.

Rosenblum, Robert (éd.), Factory Work: Warbol Wyeth Basquiat, Hanover, University Press of New England, 2007.

Zinzou, Senouvo Agbota, On joue la comédie, Cotonou, Éditions Haho, 1984.

\section{Notes}

1. Aimé Césaire, Discours sur le Colonialisme (Paris : Présence Africaine, 1989) 7. Aimé Césaire's Discours sur le Colonialisme raged against colonization as a form of extreme capitalism, a capitalism of which America is the greatest and most redoubtable proponent.

2. Césaire, Discours 29.

3. Aristide Tarnagda and Gustave Akakpo have had their works performed regularly in Africa, as well as in Limoges at Le Festival des Francophonies. They have been read at France's La Comédie Française (Spring 2015). Tarnagda now directs les Récréatrales in Ouagadougou, Burkina Faso, certainly the most courageous theatre festival in Francophone Africa.

4. Chalaye speaks in particular of the hybrid, even monstrous, assemblage that constitutes many contemporary African texts, texts that draw on many theatrical traditions, all in signaling in oblique ways Africa.

5. In the second and third part of her trilogy (Sacrifices and Tombeau), Miano connects $19^{\text {th }}$-century Jamaican slave revolts and a $21^{\text {st }}$-century return to African roots by an African-American as part of a vast network linking continental Africans and the diaspora. Interestingly, she evacuates France and the francophone diaspora in her particular configuration.

6. Pim Higgginson in Scoring Jazz notes ironically, nonetheless, how the French themselves, in thrall to jazz, had already inscribed its power to blackness, thereby distancing themselves from its creation. Higginson's study examines especially the connection between jazz and the novels of Ousmane Socé Diop, Emmanuel Dongala, Mongo Béti, Kagni Alem, and Fiston Mwanza Mujila.

7. Until he died of a drug overdose, Jean-Michel Basquiat (1960-1988), was a key visual artist within the wild art scene of New York City of the 1980s - associated with Andy Warhol and the notion of making art in order to mock both the museum establishment and the commodification of culture in an increasingly materialistic America. From his pithy work as graffitist with Al Diaz under their joint signature SAMO, to his fronting of his own noise band, Gray, to his mind-reeling success as a painter, Basquiat combined in frequently vibrant colors abstraction, figuration, pop-art or cartoon-like graphics, collage, and text in an entirely original way. Fela Kuti (19381997) was, contrary to Basquiat, from an influential and powerful family. However, like the middle-class Basquiat, he also hoped through his art to impact political thinking. Throughout the 70s, 80s, and 90s, growing ever more famous, Fela developed a musical style that combined European band instruments, polyrhythmic African percussion, and US funk and jazz, while also establishing a political persona who railed against the corruption of successive Nigerian dictators. Tejumola Olaniyan indeed suggests that 
Fela's own embodied antics held up a mirror to the incredible outlandish infractions of postcolonial African governments.

8. Obviously this ambition to be recognized as a world artist and not hemmed in by any specific category is also Koffi Kwahulés.

9. In a recently released vimeo of Kwahulé speaking about his writing process, on the occasion of winning France's Grand prix de la literature dramatique, he notes that music gives him his structure and that if he had been a painter, his painting would have been musical. (Vimeo number 248352314, accessed Jan. 8, 2018).

10. While we are not speaking directly of scenic writing or staging, we did have the opportunity to see productions of both plays: SAMO (directed by Laëtitia Guédon at La Manufacture des (Eillets) in March 2017 and Kalakuta Dream (a staged reading directed by Armel Roussel for RFI at the Avignon Theatre Festival) in July 2017.

11. In Guédon's staging, the role of Basquiat was doubled - played by an actor and a dancer. A DJ, who mixed music live, played the voice of Basquiat's father.

12. Ekow Eshun, "Bowie, Bach, and Bebop: How Music Powered Basquiat", Nerw York Times, 22 September 2017, online.

13. Robert Farris Thompson in Graham Lock and David Murray (eds), The Hearing Eye: Jazz E Blues Influences in African American Visual Art (New York : Oxford University Press, 2009) 261.

14. Thompson, The Hearing Eye 260.

15. Thompson, The Hearing Eye 266.

16. Koffi Kwahulé, SAMO: a tribute to Basquiat (Not published, paginated) 5.

17. Kwahulé, $S A M O 6$.

18. Kwahulé, SAMO 35.

19. Richard Powell quoted by Thompson, The Hearing Eye 4-5.

20. Kwahulé, SAMO 7.

21. Charles Baudelaire, "Invitation au voyage." Les Fleurs du mal (Paris, Gallimard, 1996) 88-90. Kwahulé, SAMO 16. Koffi Kwahulé, Kalakuta Dream: a tribute to Fela (Not published, paginated) 31 .

22. Thompson, The Hearing Eye 268.

23. Kwahulé, SAMO 9.

24. Prior to 2015, Kwahulé had engaged primarily with the music of jazz artists, such as Thelonius Monk (Big Shoot, Misterioso, Cette vieille magie noire), John Coltrane (Cette vieille magie noire, Big Shoot), and Louis Armstrong (Blues-S-Cat) by calling on their music in his stage directions for establishing emphasis or mood or by scoring his dialogue as though improvised by them.

25. Marshall W. Stearns quoted by Thompson, The Hearing Eye 268.

26. Kwahulé, SAMO 19.

27. Kwahulé, SAMO 11.

28. Thompson, The Hearing Eye 268.

29. Kwahulé, SAMO 18.

30. Kwahulé, $S A M O 16$.

31. Kwahulé, SAMO 22. 
33. Basquiat quoted in Basquiat xxvi.32. Robert G. O'Meally, Brent Hayes Edwards, and Farah Jasmine Griffin (eds), Uptown Conversation: the new jazz studies (New York : Columbia University Press, 2004) 364.

34. In Guédon's production of $S A M O$, the rhythmic, dashing quality of Basquiat's work and Kwahulés list were intelligently staged as a boxing sequence. Also referencing the sport that heavily influenced Basquiat, the staging choice - in which the actor playing Basquiat punches, jabs, ducks, sways, and bobs - gives to the seemingly improvised riff the texture, movement, energy, and tempo of a Basquiat canvas.

35. Kwahulé, Kalakuta Dream 2.

36. Sandra Isadore never lived in Stockbridge. She was always a Californian. But Kwahulé encapsulates with this image the dream of white (and not multiracial or multicultural) America.

37. This vignette is based on a real-life experience in which police attempted to make Fela give them, through purging him, the evidence of his marijuana smoking. He immortalized the consequences in the recording "Expensive Shit."

38. In Roussel's staged reading, the musicians, who were on stage with the actors, played under the actors'text and during the transitions between scenes, resulting in a performance that was almost entirely scored. 